\title{
Federal Reserve System International Facilities
}

\author{
Bruce Mizrach, Professor of Economics, Rutgers University \\ Christopher J. Neely, Vice President and Economist
}

T he international spread of the COVID-19 virus has created unprecedented uncertainty about near-term global economic conditions. Such uncertainty prompted investors to sell their risky assets in favor of very safe assets, such as Treasury securities. U.S. stock prices plunged, and yields on all but the safest bonds soared. Such sales tend to drive down the prices of risky assets further. Falling asset prices and heightened uncertainty often make credit more expensive and difficult to get. ${ }^{1}$ Financial markets were very troubled during almost the whole of March.

The March 2020 flight to safety included a shift to relatively safe U.S. dollar (USD) assets. As a result, the tradeweighted USD appreciated by 7 percent from March 9 to 24 (Figure 1). Over the same period, economic uncertainty substantially widened bid-ask spreads and raised the foreign exchange trading volume, which reached 540 billion USD per day on FXall, the most active interdealer trading network (Figure 2). ${ }^{2}$ Figure 3 shows that the USD also appreciated during September 2008, which was the heart of the Financial Crisis of 2007-09.

Fed lending to foreign central banksfor them to provide emergency lending aids the U.S. economy by stabilizing international financial markets.

The Federal Reserve System has responded to dysfunction in domestic equity and bond markets by supplying short-term credit and purchasing assets. Such purchases increase the liquidity of those assets and prevent the market from shutting down. The Fed was able to take such supportive action because it can create USD, but the financial turmoil has also affected international markets.

The USD is not only used on U.S. markets but also very widely in international finance; it is by far the most commonly held currency for foreign exchange reserves. At the end of 2019, the USD had a 60.9 percent share of total foreign reserves, while the euro was a distant second at 20.5 percent (Figure 4 ).

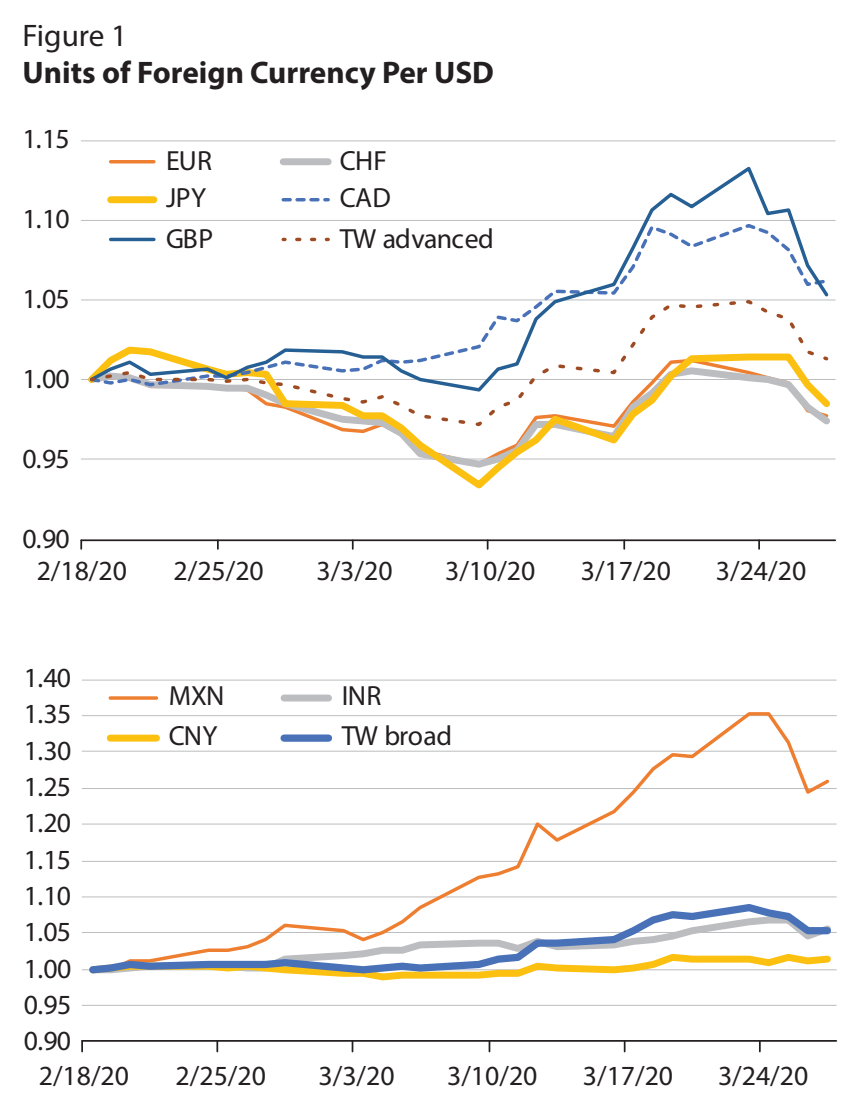

NOTE: The upper panel shows the normalized foreign exchange value of the USD against the euro (EUR), Japanese yen (JPY), British pound (GBP), Swiss franc (CHF), Canadian dollar (CAD), and narrow trade-weighted value of the USD (TW advanced). The lower panel shows the normalized foreign exchange value of the USD against the Mexican peso (MXN), Chinese renminbi (CNY), Indian rupee (INR), and broad trade-weighted value of the USD (TW broad). All series are normalized to equal 1 on February 18, 2020, to facilitate comparisons and calculations of percentage changes. SOURCE: FRED ${ }^{\circledR}$, Federal Reserve Bank of St. Louis.

To provide USD-denominated credit to firms in their markets, foreign central banks can obtain USD in any of three ways: by selling their USD foreign exchange reserves, by buying USD on foreign exchange markets, or by borrowing USD. Any of these actions can have potentially undesirable effects on asset prices. That is, selling USDdenominated foreign exchange reserves or borrowing USD tends to drive up U.S. yields, while buying USD in foreign exchange markets tends to drive up the value of the USD, which tends to reduce U.S. net exports. 
Figure 2

Monthly Foreign Exchange Trading Volume: Refinitive FX Average Daily Volumes (USD billions)

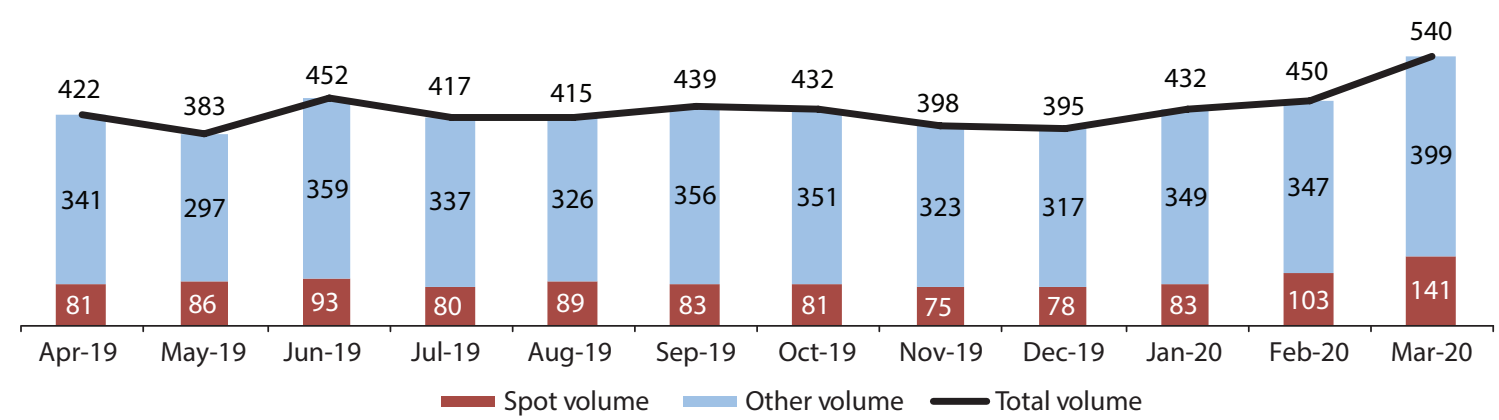

SOURCE: Refinitiv; https://www.refinitiv.com/en/products/fxall-electronic-trading-platform.

Figure 3

The USD Appreciates During Financial Crises

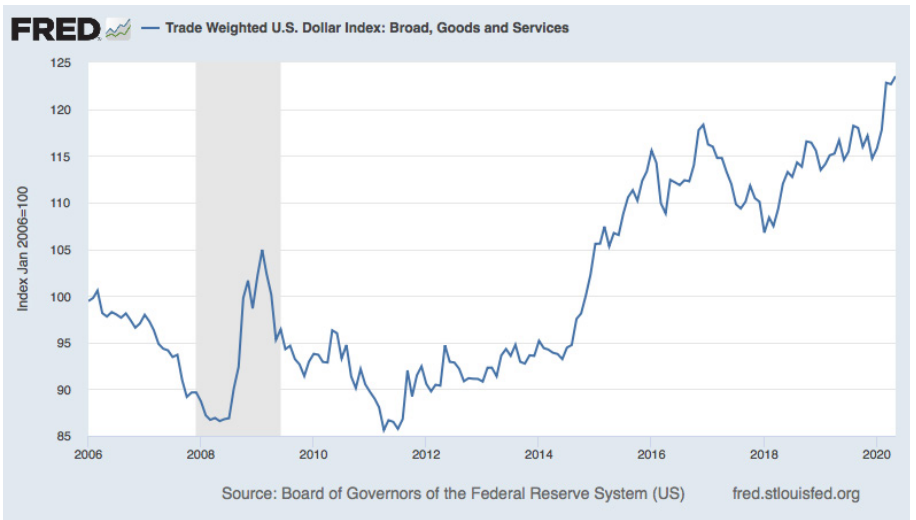

NOTE: Gray bar indicates recession as determined by the National Bureau of Economic Research.

SOURCE: SOURCE: FRED ${ }^{\oplus}$, Federal Reserve Bank of St. Louis;

https://fred.stlouisfed.org/series/DTWEXBGS.

The Fed has responded to this international demand for USD by expanding foreign exchange swap lines with other central banks and by creating a temporary liquidity facility from which foreign and international monetary authorities can borrow USD from the Fed.

Foreign exchange swaps combine spot and forward foreign exchange transactions in which one party buys foreign currency today and simultaneously sells it forward at a pre-specified price, which reflects the difference in interest rates on the currencies. Currency swaps entail minimal risk because the swapped currency functions as collateral. Swap lines enable central banks to function as a lender of last resort in a foreign currency, mitigating the consequences of fire sales of risky assets. The Fed has traditionally used swap lines to help manage financial crises. The central bank employed them, for example, both after September 11, 2001, and during the Financial Crisis of 2007-09.
Figure 4

Shares of Foreign Exchange Reserves by Currency in 2019:Q4

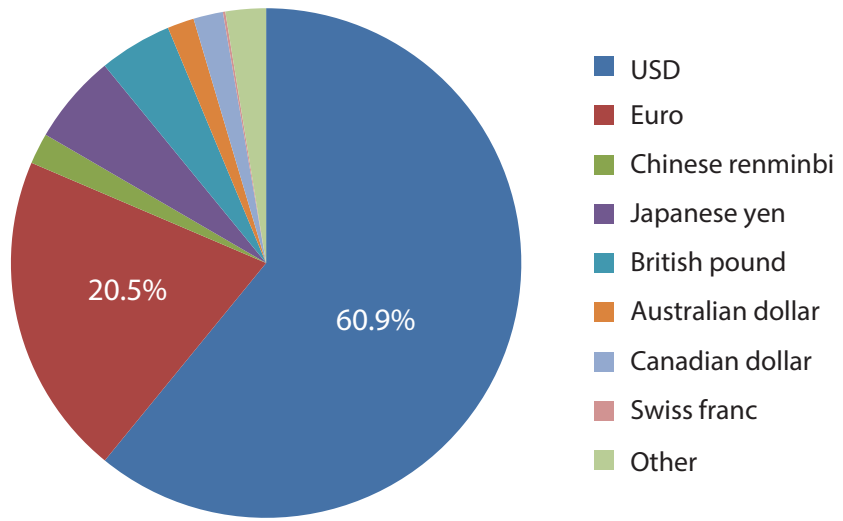

SOURCE: International Monetary Fund.

Prior to the current crisis, the Fed had standing swap lines with the Bank of Canada, the Bank of England, the European Central Bank, the Bank of Japan, and the Swiss National Bank. On March 15, 2020, the Federal Reserve lowered the interest rate paid on the USD portion of these swaps to the overnight index swap rate plus 25 basis points. ${ }^{3}$ To reduce rollover risk, the Fed added a much longer swap maturity, 84 days, to the previous one-week operations.

To broaden the availability of USD credit, on March 19, 2020, the Fed added new swap lines with the Reserve Bank of Australia, the Banco Central do Brasil, the Danmarks Nationalbank (Denmark), the Bank of Korea, the Banco de Mexico, the Norges Bank (Norway), the Reserve Bank of New Zealand, the Monetary Authority of Singapore, and the Sveriges Riksbank (Sweden). Each of these authorities is limited to 30 to 60 billion USD.

Figure 5 summarizes the total amounts swapped in 115 operations with foreign central banks through April 16, 2020. 
Figure 5

\section{Foreign Currency Swap Lines in USD}

USD millions

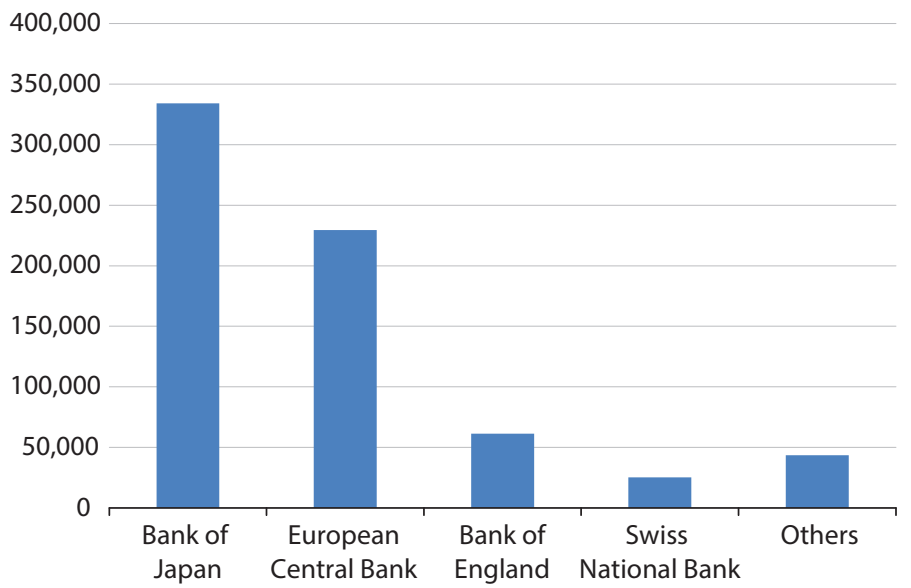

NOTE: The figure shows cumulative swap line transaction amounts from March 4, 2020, to April 16, 2020.

SOURCE: Federal Reserve Bank of New York.

Finally, on March 31, 2020, the Fed created a temporary repurchase agreement (secured borrowing) facility for a very broad set of foreign and international monetary authorities (FIMA Repo Facility). This facility began operations on April 6, 2020, and will last for at least six months. Such a facility exposes the Fed to little risk because the Fed receives Treasury bonds as collateral for the loan. The goal was to allow foreign authorities, particularly those with large USD foreign exchange reserves, direct access to USD liquidity to support the functioning of international financial markets.

By making USD available to foreign central banks to provide emergency lending abroad, the Fed indirectly aids the U.S. economy by improving conditions for our trading partners.

\section{Notes}

${ }^{1}$ A substantial decline in the prices of risky assets makes credit more expensive and difficult to obtain because lenders are less willing to lend to borrowers with lower net worth-even at higher interest rates.

2 The foreign exchange market has the highest trading volume of any market, with 6.6 trillion USD daily turnover (BIS, 2019). Schrimpf and Sushko (2019) estimate that 57 percent of this turnover occurs on electronic interdealer platforms as of April 2019, and a 2018 Euromoney (2018) survey found the Refinitiv FXall platform had a dominant 35 percent market share among such platforms.

${ }^{3}$ An overnight index swap (OIS) rate is a short-term interest rate on unsecured (no collateral) borrowing.

\section{References}

BIS. “Foreign Exchange Turnover in April 2019." September 16, 2019; https://www.bis.org/statistics/rpfx19 fx.htm.

Euromoney. "FX Survey 2018." May 30, 2018; https://www.euromoney.com/article/b18c2707zvh3yy/fx-survey-2018-multidealer-platform-rankings.

Schrimpf, A. and Sushko, V. "FX Trade Execution: Complex and Highly Fragmented." BIS Quarterly Review, December 2019; https://www.bis.org/publ/qtrpdf/r_qt1912g.htm. 